\title{
A new method for the detection and enumeration of manganese oxidizing and reducing microorganisms
}

\author{
W. E. Krumbern \& H. J. Altmann* \\ Biologische Anstalt Helgoland (Meeresstation); \\ Helgoland, Federal Republic of Germany
}

KURZFASSUNG: Eine neue Methode zum Nachweis und zur Zählung von Mangan oxidierenden und reduzierenden Mikroorganismen. Berbelinblau I (N.N'-Dimethylamino-p, $\mathrm{p}^{\prime}$-triphenylmethan-o"-sulfonsäure) ist die Leukobase eines neuen Farbstoffes und bildet mit Mn(III)$\mathrm{Mn}(\mathrm{VII})$-kationen einen intensiv blau gefärbten Farbstoff. Die Reaktion verläuft quantitativ, indem die Leukobase (FH) zum Farbstoff $(\mathrm{F}+$ ) oxidiert wird. Sie entwickelt sich am günstigsten in Acetatpuffer. Eine intensive und schnelle Reaktion mit anwesenden Mangan-III-VIIkationen läuft jedoch auch im pH-Bereich zwischen 4 und $\mathrm{pH} 7 \mathrm{ab}$. Bei Verwendung von konzentrierteren Lösungen von Berbelinblau I entstehen in Anwesenheit oxidierter Stufen des Mangans gut erkennbare Farbkomponenten noch bis $\mathrm{pH}$ 10. Die Verwendungsfähigkeit des neuen Farbstoffes als Beimengung zu Nährböden wurde getestet. Mangan oxidierende Bakterien und Pilze wachsen auf Nährböden, in denen der Farbstoff in Konzentrationen zwischen $10^{-4}$ und $10^{-5} \mathrm{~g} / 100 \mathrm{ml}$ imprägniert wurde, ohne erkennbare Behinderung gegenüber nichtbehandelten Nährböden. Bereits früher als die Bildung von schwarzbraunen Manganoxidhydratablagerungen im Nährboden tritt eine Blauverfärbung der Kolonien ein, die Mangan oxidieren. Berbelinblau I eignet sich deshalb ausgezeichnet für die Früherkennung von Mangan oxidierenden Mikroorganismen in selektiven Nährböden. Bei einem Vergleich der Benzidinmethode nach FEIGL (1958) mit dem neuen Farbstoff ergab sich ein erkennbarer Vorteil von Berbelinblau I. Das Testreagens kann dem Nährboden oder den Kulturen in schwach saurem Puffer zugeführt werden und die Isolation von Mikroorganismen ist nach Anfärbung noch ohne weiteres möglich. Kulturen und Kolonien von Mangan reduzierenden Bakterien und Pilzen lassen sich deutlich von unspezifischen Kolonien unterscheiden, wenn nach der Anfärbung mit Berbelinblau ungefärbte Höfe gezählt werden. Auch in diesem Fall ist eine Isolation ohne weiteres möglich, während dies bei der Verwendung von FEIGIS Reagens in konzentrierter Essigsäure auf Schwierigkeiten stößt. Quantitative Bestimmung von Mangan (und Sauerstoff über die Winklermethode) in Nährböden und bakteriell gefällten Manganablagerungen ist ohne weiteres möglich.

\section{INTRODUCTION}

Since first reports on manganese-oxidizing micro-organisms (MoLxscr 1910, BEIJERINCK 1913, 1915; WinogradSKI 1922 and others), work on biological manganese metabolisation has developed considerably. Media favouring the population growth of such organisms are numerous and may be separated into several groups.

(1) Media for cultivation of organisms of the Sphaerotilus-Leptothrix-group:

* Institut für Hygiene des Ruhrgebietes, Gelsenkirchen. 
Autotrophic growth and reproduction of these organisms and energy gains by iron and manganese oxidation have been discussed previously (PRINGsherm 1949, MULDeR \& VAN VeEN 1963). They need low concentrations of organic matter for growth. Growth and manganese oxidation have been controlled by occurrence of bladk-brown deposits on and close to the cells.

(2) Media for enumeration and enrichment of heterotrophic bacteria and fungi oxidizing or reducing manganese. These organisms have been described from various environments (Beijerinck 1913, Brompield \& Skerman 1950, Möse \& Brantner 1970, SCHwEISFURTH 1968). Growth and occurrence of manganese oxide deposits have been controlled by occurrence of brown deposits or by the benzidine reagent after FeIgl (1958).

(3) Media for the cultivation of manganese-oxidizing fungi which are thought to be the symbiont of Metallogenium (Zavarzin 1964a, b, Dubinina 1970).

Isolation and description of manganese-oxidizing and reducing organisms from the marine environment has been carried out by THIEL (1925), EHRLICH (1963), EHRlich et al. (1972), Kalinenro et al. (1962) and Krumbern (1971). Graham \& CooPER (1959) suggest biogenic deposition of manganese minerals in the sea without having conducted cultivation experiments. In case of quantitative and especially qualitative determination of manganese oxidation or reduction, most of the authors have used benzidinium-chloride solution in concentrated acetic acid as suggested by FEIGL (1958).

On several cruises with R.V. "Friedrich Heincke" in the Bay of Biscay, the Baltic Sea and the North Sea we have determined quantitative distribution of manganeseoxidizing and reducing micro-organisms heterotrophic and autotrophic bacteria in recent marine sediments. During these cruises we have frequently observed dark brown and black or blue-black to green-black pigmented bacteria and fungi falsifying results of direct reading without chemical tests. In addition, we observed weak oxidizers which give no brown-black deposits at all. The same has been reported by EHrIICH et al. (1972). This led us to look for another suitable method for the detection of biological manganese oxidation and/or reduction.

One of us (ALTMANn 1972) synthetized a new triphenyl-compound sensitive to Mn III to Mn VII but insensitive to Mn II and other metals in trace concentrations. This reagent seemed suitable for detection and enumeration of manganese metabolising micro-organisms. Cultivation experiments in the laboratory and field trips were conducted to test the new reagent.

\section{MATERIAL AND METHODS}

During experiments with marine manganese-oxidizing organisms and heterotrophic bacteria and fungi capable of reducing $\mathrm{Mn}$ IV-compounds, we have tested altogether 15 different media, of which the most suitable are cited below:

(a) Manganese oxidation by marine heterotrophic bacteria: Difco-Bacto-peptone, 2-5 g; Difco-yeast extract, 0.5-1 g; $\mathrm{MnSO}_{4} \times \mathrm{H}_{2} \mathrm{O}, 100-200 \mathrm{mg} ; \mathrm{FeSO}_{4} \times 7 \mathrm{H}_{2} \mathrm{O}$, traces; agar (Difco-Bacto-agar), $15 \mathrm{~g}$; aged sea water, $750 \mathrm{ml}$; distilled water, $250 \mathrm{ml}$; $\mathrm{pH}, 7.6$. 
(b) Manganese oxidation by marine fungi: Malt extract (Biomalz, Andreas $\mathrm{Kg}$, Kirn, Germany, but other malt products should do as well), 1-2 g; $\mathrm{MnSO}_{4} \times \mathrm{H}_{2} \mathrm{O}$, $100 \mathrm{mg} ; \mathrm{FePO}_{4}, 10 \mathrm{mg}$; Difco-Bacto-agar, $15 \mathrm{~g}$; aged sea water, $750 \mathrm{ml}$; distilled water, $250 \mathrm{ml} ; \mathrm{pH}, 6.4$.

(c) Manganese-reducing micro-organisms: Peptone 2-5 g; Glucose, $2.5 \mathrm{~g}$; $\mathrm{FePO}_{4}$, $10 \mathrm{mg}$; Difco-Bacto-agar, $15 \mathrm{~g}$; artificial, manganese-free sea water, $1000 \mathrm{ml} ; \mathrm{pH}, 7.6$. After sterilisation and cooling to $48^{\circ} \mathrm{C} 1-1.5 \mathrm{ml}$ of $2 \% \mathrm{KMnO}_{4}$-solution is added per $100 \mathrm{ml}$ of medium prior to pouring plates.

(d) Manganese reduction by marine micro-organisms: Peptone, $2-5 \mathrm{~g}$, glucose, $2.5 \mathrm{~g}, \mathrm{MnO}_{2}, 2-5 \mathrm{~g}$ (the $\mathrm{MnO}_{2}$ powder delivered by the chemical companies has to be ground sometimes to finer grain size to obtain better suspension and surface ratios); manganese-free artificial sea water, $1000 \mathrm{ml} ; \mathrm{pH}, 7.6$.

Iron phosphate was added to the media since iron is rapidly flocculated in sea water, and its addition often enhances growth of marine micro-organisms by releasing traces of iron and phosphate. All media have been tried with success also without addition of agar in shaking incubators.

Reagent: Berbelin blue-I (N.N'-Dimethylamino-p,p'-triphenylmethane-o"-sulphonic acid). Synthesis and specifications of the reagent are described by ALTMANN (1972). The reagent is available from Mecron GmbH (D-1 Berlin, Hauptstr. 76, Germany).

The leucobase of the above-mentioned triphenyl compound is oxidized in a few seconds to the colour compound in the presence of Mn III-Mn VIII. Mn II and other metals do not influence the leucobase. In case of quantitative estimations of $\mathrm{Mn}$ or oxygen, the colour is measured for optical density at $618 \mathrm{~nm}$ with any commercial photometer.

The reagent may be stored in the dark at $7^{\circ} \mathrm{C}$ for several weeks before the oxidized form builds up on the crystal surfaces. In this case, a faint blue colour occurs on the originally white crystals. The aqueous solution is stable for more than a year if several drops of $\mathrm{NH}_{4} \mathrm{OH}$-solution are added. The optical density is not influenced by acetate buffer.

A concentrated stock solution of Berbelin blue-I has been prepared as follows: $4 \mathrm{~g}$ Leukoberbelin blue I are dissolved in $80 \mathrm{ml}$ of boiled distilled water (prior to distillation the water was acidified with phosphoric acid), $0.3 \mathrm{ml}$ of concentrated $\mathrm{NH}_{4} \mathrm{OH}$ solution are added and the solution is filled up to $100 \mathrm{ml}$. This stock solution may be stored more than a year. Reaction of Berbelin blue-I-solutions with manganese particles and solutions has been checked for different concentrations and different $\mathrm{pH}$ values. It must be mentioned that at high concentrations and $\mathrm{pH}$-values between 5 and 10 reprecipitations may occur. For final test series with manganese media we prepared sub-solutions of $0.4 \mathrm{~g} / 100 \mathrm{ml}$ which were added to media in portions between 0.1 and $10 \mathrm{ml} / 100 \mathrm{ml}$ of medium. For manganese tests after cultivation by addition of test reagent to the Petri dishes we used solutions from $0.2 \mathrm{~g} / 100 \mathrm{ml}$ to $1 \mathrm{~g} / 100 \mathrm{ml}$. The test was successful between $\mathrm{pH} 3.5$ and 10 . The optimal results are observed at $\mathrm{pH} 4-6$.

Parallel tests were run with FEIGL's reagent $(5 \mathrm{~g}$ Benzidinium-hydrochloride are dissolved in $35 \mathrm{ml}$ concentrated acetic acid and filled up to $500 \mathrm{ml}$ with distilled water). 
Plate counts were made before treatment with any of the reagents by counting colonies which showed brown or black pigmentation or precipitates.

\section{RESULTS}

Test series have been run with pure cultures of manganese-oxidizing fungi and bacteria inoculated to manganese media containing various concentrations of Berbelin-I prior to inoculation and to media without Berbelin-I solutions. In the latter case, results were checked after 3 weeks of culture, first by counting brown colonies then by adding FEIGL's reagent of Berbelin-I solutions.

Table 1 gives results of the test series with Berbelin-I solutions added prior to inoculation compared to the occurrence of brown spots due to manganese oxidation.

Another series of experiments was carried out by incorporation of Berbelin blue-I solutions to media which then were inoculated by suspension dilutions of recent sediments from the North Sea. Results of this experiment are given in Table 2.

Table 1

Comparison of positive reactions after 4,10 , and 28 days of culture for different pure strains of manganese oxidizers on medium $b$. First column indicates degree of blue colour at the place of colonies in Berbelin-I-impregnated media. Second column indicates degree of brownblack manganese colours on parallel inoculates without addition of Berbelin blue-I. Number of colonies / plate arerages 5-15 colonies

\begin{tabular}{|c|c|c|c|c|c|c|c|}
\hline \multirow[b]{2}{*}{$\begin{array}{l}\text { Strain } \\
\text { Nr. }\end{array}$} & \multirow{2}{*}{$\begin{array}{c}\text { Concentration } \\
\text { of Berbelin-I } \\
(\mathrm{mg} / \mathrm{l})\end{array}$} & \multicolumn{2}{|c|}{ After 4 days } & \multicolumn{2}{|c|}{ After 10 days } & \multicolumn{2}{|c|}{ After 28 days } \\
\hline & & $\begin{array}{c}\mathrm{I} \\
\text { (blue) }\end{array}$ & (brown) & $\begin{array}{c}\mathrm{I} \\
\text { (blue) }\end{array}$ & $\begin{array}{c}\text { II } \\
\text { (brown) }\end{array}$ & $\begin{array}{c}\mathrm{I} \\
\text { (blue) }\end{array}$ & $\begin{array}{c}\text { II } \\
\text { (brown) }\end{array}$ \\
\hline $6646 b$ & $8 \mathrm{mg} / 1$ & - & - & $t+t$ & + & ++ & +++ \\
\hline $6721 \mathrm{~b}$ & & - & - & + & + & ++ & +++ \\
\hline 7729 & & - & - & + & - & & +1 \\
\hline 542 & & 一 & - & + & + & $\frac{t}{t}+$ & $+t+$ \\
\hline $\begin{array}{r}759 \\
7679\end{array}$ & & 二 & E & $F+$ & $\begin{array}{l}+ \\
+\end{array}$ & + & + \\
\hline 7679 & & 一 & 一 & & & & $+T$ \\
\hline $6646 \mathrm{~b}$ & $40 \mathrm{mg} / \mathrm{l}$ & - & - & $+t$ & + & $+t+$ & $t+t$ \\
\hline $6721 b$ & & - & - & $+t+$ & + & $++t$ & $t+$ \\
\hline 7729 & & 一 & 一 & ++ & - & +++ & + \\
\hline 542 & & - & 一 & ++ & + & +++ & $+t$ \\
\hline 759 & & - & - & + & - & ++ & - \\
\hline 7679 & & 一 & - & ++ & - & ++ & + \\
\hline $6646 \mathrm{~b}$ & $80 \mathrm{mg} / 1$ & + & 一 & $+t+$ & $t$ & $++t$ & $+t$ \\
\hline $6721 b$ & & $\frac{t}{2}$ & - & $t+t$ & - & $+t+$ & $t+t$ \\
\hline 7729 & & - & - & $+\div$ & + & ++ & $t+$ \\
\hline 542 & & 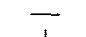 & - & $+t+$ & - & $\begin{array}{l}+t+ \\
t+\end{array}$ & + \\
\hline $\begin{array}{r}759 \\
750\end{array}$ & & + & - & $t^{t}+1$ & F & ++ & $\overline{+}+$ \\
\hline 7679 & & t & - & $T+T$ & t & +++ & $+t$ \\
\hline $6646 \mathrm{~b}$ & $200 \mathrm{mg} / \mathrm{l}$ & - & - & $++t$ & ++ & +++ & $+t+$ \\
\hline $6721 \mathrm{~b}$ & & + & 一 & $t+t$ & + & ++1 & ++ \\
\hline 7729 & & + & - & ++ & ++ & ++ & $t+t$ \\
\hline 542 & & - & 一 & ++ & ++ & ++ & $+t$ \\
\hline 759 & & 一 & - & ++ & $t$ & $+t$ & + \\
\hline 7679 & & + & - & + & - & t & - \\
\hline
\end{tabular}




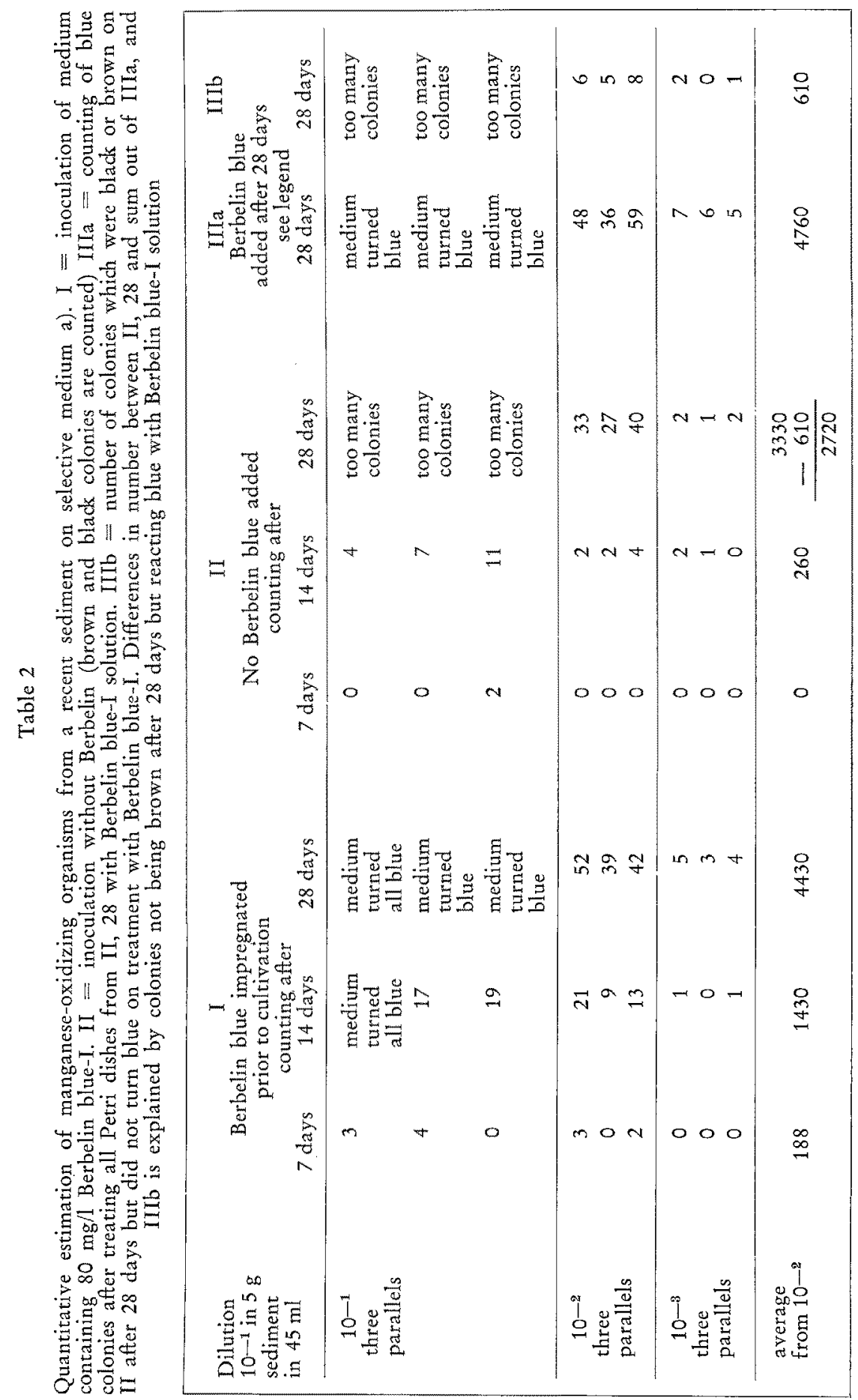


From Table 1 we can see that Berbelin blue-I incorporated in media reacts rapidly with traces of precipitated Mn IV compounds and as well with Mn IV or Mn III ions in solution. This allows faster and more exact detection than mere observation of brown-black deposits occurring.

Data in Table 2 indicate, that Berbelin blue-I incorporated in enrichment media allows separation of dark bacteria and fungal pigments from real manganese oxide precipitates. It should be stated, nevertheless, that heavy manganese-oxide production in the Petri dish leads, after some time, to migration of the colour and may falsify the results. Parallel tests with addition of Berbelin I solutions to the culture flasks or Petridishes after incubation resulted in better limited coloured zones at places of manganese

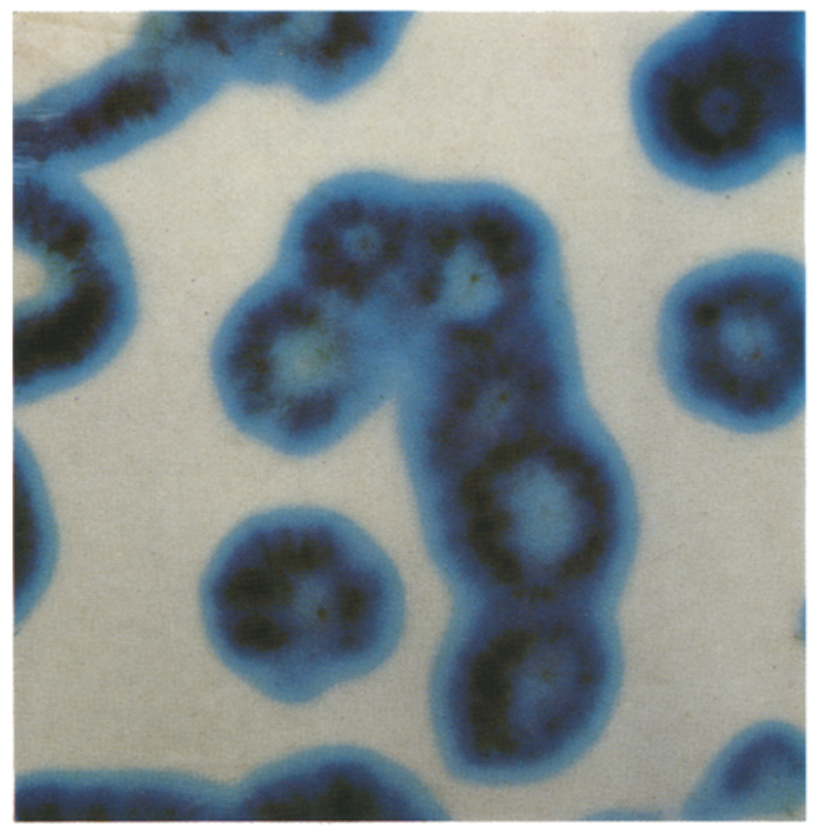

Fig. 1: Pure culture of manganese oxidizing fungus with light centers and brown deposits of manganese oxides. (Scale 1.4:1)

oxidation, since migration of colour compounds formed did not occur. Generally, impregnation of media for manganese oxidation with Berbelin blue-I gave positive results, but addition of Berbelin blue I to media after incubation was as effective and proved to be more accentuated in its immediate action on total precipitates. Counting on solid agar plates must be carried out between 2-10 minutes after treatment since some time is needed for the reagent to migrate through the agar and react with manganese-oxide hydrates. Reduction of manganese by micro-organisms is indicated by colourless halos in manganese (VII) or manganese (IV)-impregnated media at the places where reduction took place. The colour compound is not reduced quantitatively once it has reacted with oxidized manganese and is exposed to reducing chemicals. 
Therefore, impregnation of Berbelin-I to media for enrichment of manganese-reducing organisms is not suitable.

Figures 1 and 2 give an impression of differentiation of manganese oxidizing microorganisms with and without Berbelin blue-I. Figures 1 and 2 show a pure culture of manganese oxidizing fungus before and after treatment with Berbelin blue-I. The center of fungal colonies frequently shows zones of little oxidation sometimes (mainly on media with organic manganese salts) even reducing parts. Oxidized manganese salts invisible in brown photograph will be coloured blue after treatment with reagent. Parts of the mycelium will sometimes oxidize only iron. This may be shown by microscopic preparations of colonies treated with reagent.

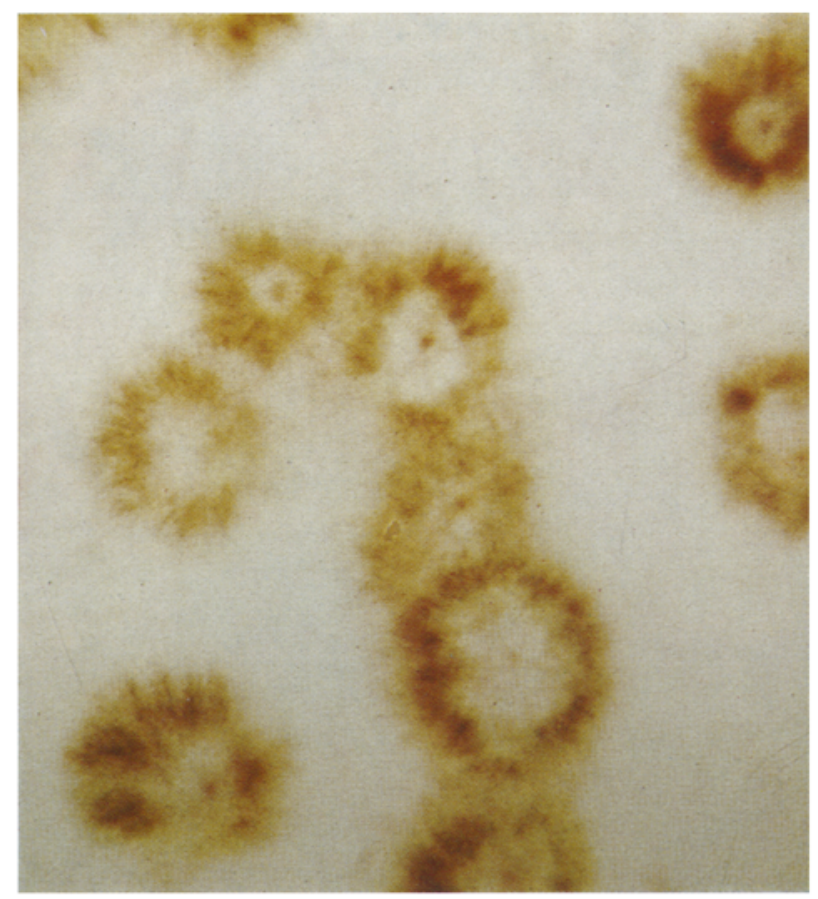

Fig. 2: Culture from Figure 1 treated with Berbelin blue-I solution. (Scale 2.1:1)

In some other experiments with fungi associated with Metallogenium symbioticum the typical round spots of Metallogenium were coloured blue while fungal mycelium was brown due to iron oxidation. Treatment of microscopic slides also revealed that sometimes iron was deposited on normal mycelium while manganese oxidation took place on Clamydospores.

\section{DISCUSSION}

Various tests with Berbelin blue-I have shown advantages of this reagent in early detection of manganese oxidation and reduction by bacteria and fungi. The addition 
of low concentrations of Berbelin blue-I to media below $\mathrm{pH} 7$ and of higher concentrations of the reagent to media with $\mathrm{pH}$-values above 7 prior to incubation made direct quantitative estimation of manganese oxidizing microorganisms easier and safer than estimation of brown and black colonies. Impregnation of Berbelin blue-I solutions to media prior to or after inoculation and cultivation makes elimination of dark pigmented colonies of bacteria and fungi possible which, without the reagent, had to be differentiated by subcultivation on media with and without Mn II sources.

Direct isolation of positive colonies is possible after treatment with slightly acid Berbelin-I solutions, while isolation from plates treated with FEIGL's reagent was always difficult or impossible due to high acetic acid concentrations. Isolation had to be completed before treating with acetic acid reagent by replica plates or another subculture method.

It must be noted that Berbelin blue-I solutions which have already formed the oxidized colour compound may migrate through agar plates. Therefore, it is advisable, in case of difficulties, to add the reagent only after incubation is finished or after a certain cultivation time.

Manganese reduction by micro-organisms can be detected more easily and safely when media containing Mn VII solutions or Mn IV oxide powders are treated with Berbelin blue-I solution after cultivation.

White halos of reducing zones around bacterial and fungal colonies are much more distinct and easier to distinguish than the disappearance of the faint brownish colour of permanganate or black particles of oxide or powdered manganese nodules.

Manganese oxidation in liquid media may be detected very fast and long before brown or black deposits are visible at the bottom of the culture flasks.

It is important to change the concentration of the reagent when $\mathrm{pH}$ of media is rised above 6.7. The reagent gives positive results even at $\mathrm{pH} 8-10$ when higher concentrations are applied. In this case, the blue colour may turn to blue-green. The reagent is not affected by other elements at concentrations occurring in fresh water, seawater or sediments. Care has to be taken in the case of cultural work with crushed manganese nodules, since small nodule particles may sometimes be taken for bacteria colonies with blue halo.

Ecological work on the distribution of manganese-oxidizing or reducing microorganisms on board research vessels is easier and less dangerous with Berbelin blue-I solutions than with FeIGL's reagent which usually gives the best results in concentrated acetic acid. Relations to manganese concentration and colour stability is better than with benzidinium. [Berbelin blue-I may also be employed for quantitative $\mathrm{Mn}$ determinations and for a modified WrNKLER-oxygen method (ALTMANN 1972).]

It is advisable in cases of presence of iron in culture media to check colonies and particularly fungus mycelia after treatment with Berbelin blue-I by light microscopy. We have frequently observed colonies which were brown before treatment, that became completely blue after treatment with Berbelin blue-I yet under the microscope only small parts of the organisms were really blue while other parts were unaffected or incrusted with iron oxides. We did not check the method with cultures of Leptothrix, but it may be useful for separation of parts of the bacteria which deposit manganese from those where only iron is oxidized. 


\section{SUMMARY}

1. Berbelin blue-I (N.N.'-Dimethylamino-p, p'-triphenylmethane-o"-sulphonic acid) has been examined as a reagent for the detection of manganese oxidation and manganese reduction in microbial culture media.

2. Berbelin blue in slightly acid solution may be added to media without influencing population growth of micro-organisms. The oxidation of $\mathrm{Mn}$ II solutions to Mn III and IV is detected by occurrence of deep blue colours.

3. In case of long-term culture experiments, it is more advisable to add Berbelin blue-I solutions only after cultivation.

4. Berbelin blue-I solutions react with manganese IV-VII in $\mathrm{pH}$ ranges between 3.5 and 10 , thus allowing tests at desired $\mathrm{pH}$ values.

5. Reduction of manganese VII or manganese IV by micro-organisms may be detected by addition of Berbelin blue-I solutions after cultivation periods. White halos within dark-blue coloured media indicate reduction of Mn-IV compounds better than occurrence of white spots in slightly violet or grey media, as produced by the incorporation of manganese oxides or permanganate solutions to test media.

6. Ecological work and quantitative work on board research vessels is much easier and less dangerous with Berbelin-I solutions than with FEIGL's Benzidinium reagent.

7. Berbelin blue-I may be used for quantitative determination of manganese and oxygen when measuring optical density of the colour complex at $618 \mathrm{~nm}$ in wide concentration ranges and working in acetate buffer.

\section{LITERATURE CITED}

Altmann, H. J., 1972. Bestimmung von in Wasser gelöstem Sauerstoff mit Leukoberbelinblau I. Eine schnelle Winklermethode. $Z$. analyt. Chem. 262, 97-99.

BetJerinck, M.W., 1913. Oxydation des Manganbikarbonats durch Bakterien und Pilze. Folia microbiol., Delft 2, 123-134.

Brompield, S. M. \& Skerman, V. B. D., 1950. Biological oxidation of manganese in soils. Soil Sci. 69, 337-348.

Dubinina, G. A., 1970. Untersuchungen über die Morphologie von Metallogenium und die Beziehungen zu Mycoplasma. Z. allg. Mikrobiol. 10, 309-320.

EHRLich, H. L., 1963. Bacteriology of manganese nodules. I. Bacterial action on manganese in nodule enrichments. Appl. Microbiol. 11, 15-19.

- Ghiorse, W. C. \& Johnson, G. L., 1972. Distribution of microbes in manganese nodules from the atlantic and pacific oceans. Dev. ind. Microbiol. 13, 57-65.

FEIGL, F, 1958. Spot tests in inorganic analysis. Elsevier, Amsterdam, $600 \mathrm{pp}$.

GRAHAM, J. W. \& CoORER, S., 1959. Biological origin of manganese rich deposits of the sea floor. Nature, Lond. 183, 1050-1051.

Kalinenko, V. O., Belokopytova, O. V. \& Nikolajeva, G. G., 1962. Bacteriogenic formation of iron-manganese concretions in the Indic Ocean. Okeanologiya 11, 1050-1059.

Krumbern, W. E., 1971. Manganese oxidizing fungi and bacteria in recent shelf sediments. Naturwissenschaften 58, 56-57.

MösE, J. R. \& BRANTANR, H., 1970. Untersuchungen zur Biologischen Eisen- und Manganoxidation. Zentbl. Bakt. Parasitkde (Abt. 2) 124, 412-426.

Molisch, H., 1910. Die Eisenbakterien. Fischer, Jena, 83 pp. 
MULDER, E. G. \& VEEN, W. L. VAN, 1963. Investigations on the Sphaerotilus-Leptothrix group. Antonie van Leeuwenhoek 29, 121-153.

Pringsheim, E. G., 1949. Iron bacteria. Biol. Rer. 24, 200-245.

SCHWEISFURTH, R., 1968. Untersuchungen über manganoxydierende und reduzierende Mikroorganismen. Mitt. int. Verein. theor. angew. Limnol, 14, 179-186.

ThieL, G. A., 1925. Manganese precipitated by microorganisms. Econ. Geol. 20, 301-310.

Winogradski, S., 1922. Eisenbakterien als Anorgoxydanten. Zentbl. Bakt. Parasitkde. (Abt. 2) $57,1-21$.

Zavarzin, G. A., 1964a. The mechanism of manganese deposition on molluse shells. Dokl. Akad. Nauk SSSR 154, 944-945.

- 1964b. Metallogenium symbioticum. Z. allg. Mikrobiol. 4, 390-395.

First author*s address: Dr. W. E. KrumberN

Biologische Anstalt Helgoland

(Meeresstation)

2192 Helgoland

Federal Republic of Germany 